\title{
REMEDIASI KESULITAN MAHASISWA PGSD MENYUSUN ALAT PENILAIAN HASIL BELAJAR BERBASIS KELAS MELALUI KERJA KELOMPOK
}

\section{Realin Setiamihardja}

\begin{abstract}
Abstrak
enelitian Penelitian yang berjudul "Remediasi Kesulitan Mahasiswa PGSD Menyusun Alat

$\mathrm{P}$ Penilaian Hasil Belajar Berbasis Kelas Melalui Kerja Kelompok " dilakukan di PGSD Kampus Cibiru. Tujuan yang ingin dicapai dalam penelitian ini adalah meningkatkan kemampuan mahasiswa dalam menyusun alat penilaian hasil belajar berbasis kelas.
\end{abstract}

Kesimpulan hasil penelitian tindakan kelas ini adalah: 1) adanya peningkatan aktifitas belajar mahasiswa dalam menyusun alat penilaian bentuk pilihan ganda, isian singkat dan uraian; 2) mahasiswa memperoleh pengalaman belajar secara utuh yang saling terkait dalam kemampuan penyusunan alat penilaian hasil belajar; 3) adanya peningkatan motivasi belajar; 4) mahasiswa memperoleh pengalaman belajar yang bermakna serta menciptakan hubungan yang akrab antara mahasiswa dengan pengajar; dan 5) adanya peningkatan kemampuan mahasiswa dalam penyusunan alat penilaian hasil belajar, melalui tukar pendapat, berbagi pengalaman dan kegiatan diskusi bersama teman sekelompoknya.

Kata Kunci: Alat Penilaian, Kerja Kelompok 


\section{LATAR BELAKANG MASALAH}

Dalam keseluruhan proses belajar, pengajar yang profesional akan menunaikan tugasnya tidak hanya terbatas pada upaya menyampaikan materi pelajaran. Namun akan dituntut untuk memanfaatkan keberhasilan usahanya dalam menyampaikan materi pelajaran, yaitu dengan melakukan evaluasi hasil belajar mengajar. Karena dengan kegiatan ini dua sasaran pokok akan dicapai dalam melaksanakan evaluasi belajar-mengajar yaitu untuk mendeteksi tingkat penguasaan yang dicapai mahasiswa dan efektivitas dan efisiensi pembelajaran.Untuk melakukan penilaian hasil belajar mahasiswa, pada umumnya menggunakan tes hasil belajar.

Tes hasil belajar ini diartikan sebagai salah satu tes yang dirancang untuk mengukur tingkat penguasaan mahasiswa atau kecakapan tentang keterampilan. Adapun batasan tentang tes yang dikemukakan oleh Wiersma dan Jurs $(1991,4)$ adalah seperangkat item atau pertanyaan yang dirancang, ditujukan untuk satu atau lebih mahasiswa dengan kondisi yang berbeda. Pernyataan ini menggambarkan bahwa pertanyaan-pertanyaan yang akan diberikan kepada mahasiswa perlu dirancang terlebih dahulu.

PGSD sebagai lembaga yang menyelenggarakan program prajabatan pengajar, mengembangkan seperangkat kecakapan yang dipersyaratkan didalam melaksanakan tugas-tugas mengajar yang harus dikuasai mahasiswa calon pengajar setelah menyelesaikan pengalaman belajar yang digariskan oleh program. Sehingga mahasiswa PGSD akan memiliki kemampuan menilai proses dan hasil belajar mahasiswa (Dirjen Dikti; 1997/1998, 6). Kemampuan menilai proses dan hasil belajar mahasiswa diperoleh melalui perkuliahan Evaluasi Pengajaran di semester 5. Dengan mempelajari materi Evaluasi Pengajaran, mahasiswa diharapkan mampu memaknai hakikat pengukuran dan penilaian, menyusun perangkat alat penilaian hasil belajar untuk mahasiswa sekolah dasar, mengolah, melaporkan hasil penilaian untuk kepentingan pengajaran.

Menyusun perangkat alat penilaian hasil belajar harus direncanakan terlebih dahulu agar alat tersebut berfungsi sebagai alat yang tepat dan sesuai dengan informasi yang akan dikumpulkan. Sebelum merencanakan alat penilaian khususnya alat penilaian hasil belajar, perlu terlebih dahulu dipahami prinsip-prinsip dasar penyusunan alat penilaian hasil belajar. Karena alat penilaian tersebut merupakan salah satu alat ukur yang digunakan untuk menentukan keberhasilan seseorang dalam suatu proses belajar mengajar atau untuk menentukan keberhasilan suatu program pendidikan.

Dari hasil menyelesaikan perkuliahan Evaluasi Pengajaran mahasiswa PGSD UPI Kampus Cibiru ditemukan : (1) masih ada mahasiswa yang kurang mampu memaknai tujuan instruksional dan bahan pengajaran dengan aspek-aspek yang esensial bagi perubahan perilaku mahasiswa, (2) belum mengetahui dan memahami tentang prinsip-prinsip dan teknik-teknik yang perlu dikembangkan dalam penilaian, (3) kurang terampil dalam menyusun alat penilaian hasil belajar yang benar dan bermakna. Sehingga perangkat alat penilaian yang akan digunakan untuk melakukan penilaian terhadap hasil belajar belum memiliki kualitas yang memadai.

Dalam mempelajari materi Evaluasi Pengajaran khususnya dalam menyusun perangkat alat penilaian hasil belajar dapat dilaksanakan dengan berbagai cara, salah satu diantaranya adalah dengan mengembangkan keterampilan berkomunikasi antara mahasiswa dengan pengajar, mahasiswa dengan mahasiswa dalam latihan menyusun perangkat alat penilaian yang dilaksanakan melalui kerja kelompok agar kualitas proses pembelajaran Evaluasi Pengajaran lebih meningkat. Dalam kerja kelompok ini akan memudahkan mahasiswa bekerja sama memecahkan kesulitan saat diskusi, sumbang saran sehingga dapat meningkatkan kemampuan menyusun perangkat alat penilaian hasil belajar. Dengan kerja kelompok, mahasiswa dapat belajar dengan memenuhi 4 (empat) pilar yaitu learning to know, learning to do, learning to live together dan learning to be. 
Berdasarkan uraian di atas, mahasiswa yang belum mencapai kualitas yang diharapkan dalam merancang alat penilaian hasil belajar perlu mendapatkan bantuan untuk memecahkan kesulitannya. Bantuan yang dapat diberikan dengan melalui remedial, karena dengan remedial akan : (1) memberikan pengalaman aplikatif untuk menyusun butir-butir soal sesuai kurikulum bidang studi di SD, para mahasiswa PGSD perlu diberi latihan khusus menyusun butir-butir soal penilaian hasil belajar yang benar dan bermakna, (2) melatih pemahaman tentang model "pemaknaan" tujuan perlu diangkat sebagai bagian penting dari materi dan proses perkuliahan Evaluasi Pengajaran di PGSD, bahwa untuk menyusun butir-butir soal hasil belajar yang benar dan bermakna terlebih dahulu perlu melalui 'pemaknaan" tujuan, kemudian menyusun materi-materi evaluasi yang didasarkan pada tujuan yang telah dimaknai, baru kemudian menyusun butir-butir soal sesuai dengan teknik dan jenis tesnya

Sehubungan dengan diberlakukannya kurikulum berbasis kelas, kerangka penilaian berbasis kelas memuat prinsip, sasaran dan pelaksanaan penilaian berkelanjutan akurat dan konsisten sebagai bentuk akuntabilitas kepada publik. Kerangka ini juga memuat pertanyaan yang jelas tentang standar yang tercapai, serta peta kemajuan mahasiswa dan pelaporan kepada mahasiswa atau orang tua. Maka dalam kegiatan ini mahasiswa PGSD semester 5 yang mengalami kesulitan dalam menyusun alat penilaian mendapatkan bantuan (remedial) untuk meningkatkan kemampuannya menyusun alat penilaian hasil belajar sesuai dengan kerangka penilaian berbasis kelas melalui kerja kelompok.

\section{RUMUSAN MASALAH}

Berdasarkan uraian pada bagian terdahulu, maka rumusan masalah dalam penelitian ini adalah bagaimana pembelajaran Evaluasi Pengajaran dengan kerja kelompok dapat meningkatkan kemampuan mahasiswa PGSD semester 5 dalam menyusun alat penilaian hasil belajar untuk mahasiswa SD sesuai dengan kerangka penilaian berbasis kelas.

Rumusan masalah ini dijabarkan menjadi beberapa pertanyaan penelitian yaitu sebagai berikut :

1. Bagaimana mahasiswa PGSD semester 5 memaknai kerja kelompok dalam pembelajaran Evaluasi Pengajaran?

2. Bagaimana mahasiswa PGSD semester 5 menganalisis kurikulum tingkat satuan pendidikan dan materi bidang studi dalam rangka menyusun alat penilaian?

3. Bagaimana mahasiswa PGSD semester 5 menyusun kisi-kisi yang mengacu pada hasil analisis kurikulum dan materi bidang studi tertentu?

4. Bagaimana mahasiswa PGSD semester 5 menetapkan tujuan pembelajaran sesuai dengan kisi-kisi dan materi yang telah ditetapkan?

5. Bagaimana mahasiswa PGSD semester 5 menyusun perangkat alat penilaian bentuk pilihan ganda, isian singkat dan uraian?

\section{TUJUAN PENELITIAN}

Penelitian ini bertujuan untuk mengidentifikasikan dan mendeskripsikan hal-hal yang berkaitan dengan penggunaan kerja kelompok dalam proses pembelajaran Evaluasi Pengajaran sebagai upaya meningkatkan kemampuan mahasiswa PGSD semester 5 dalam menyusun perangkat alat penilaian hasil belajar untuk mahasiswa SD sesuai dengan kerangka penilaian berbasis kelas.

Secara khusus penelitian ini berusaha mendeskripsikan :

1. Meningkatkan pemaknaan mahasiswa PGSD semester 5 terhadap kerja kelompok dalam pembelajaran Evaluasi Pengajaran. 
2. Meningkatkan kemampuan mahasiswa PGSD semester 5 menganalisis kurikulum tingkat satuan pendidikan dan materi bidang studi dalam rangka meyusun perangkat alat penilaian.

3. Meningkatkan kemampuan mahasiswa PGSD semester 5 menyusun kisi-kisi yang mengacu pada hasil analisis kurikulum dan materi bidang studi yang telah ditetapkan.

4. Meningkatkan kemampuan mahasiswa PGSD semester 5 menetapkan tujuan pembelajaran sesuai dengan kisi-kisi dan materi yang telah dibuat.

5. Memperoleh hasil yang optimal dari kerja kelompok untuk meningkatkan kemampuan mahasiswa PGSD semester 5 menyusun perangkat soal bentuk pilihan ganda, isian singkat dan uraian.

\section{TINJAUAN PUSTAKA}

\section{Kerja kelompok}

Teknik ini merupakan suatu cara mengajar, dimana peserta didik di kelas dipandang sebagai satu kelompok atau dibagi menjadi bebarapa kelompok. Setiap kelompok terdiri dari 5 atau 7 peserta didik. Mereka bekerja sama dalam memcahkan maslah, atau melaksanakan tugas tertentu dan berusaha mencapai tujuan pembelajaran yang telah ditetapkan.

Robert L. Gilstrap dan William R. Martin memberikan pengertian kerja kelompok sebagai kegiatan sekelompok peserta didik yang biasanya berjumlah kecil, yang diorganisir untuk kepentingan belajar. Keberhasilan kerja kelompok ini menuntut kegiatan yang kooperatif dari beberapa individu tersebut (Roestiyah N.K : 1989,15). Kerja kelompok ini ditandai oleh (1) adanya tugas bersama, (2) pembagian tugas dalam kelompok, (3) adanya kerja sama antara anggota kelompok dalam menyelesaikan tugas kelompok.

Dengan kerja kelompok diharapkan terpupuk kemauan dan kemampuan kerja sama antar anggota kelompok, meningkatnya keterlibatan mahasiswa, emosional dan intelektual para peserta didik dalam proses belajar-mengajar dan meningkatnya perhatian terhadap proses dan hasil belajar-mengajar secara seimbang (Moedjiono \& M.Dimyati : 1991-1992,61). Selain itu para peserta didik dalam kerja kelompok akan memperoleh kesempatan mengembangkan keterampilan berkomunikasi dan membahas suatu masalah. Lebih intensif dalam memecahkan masalah dan memperoleh kesempatan untuk mengembangkan rasa saling menghargai dan menghormati, saling membantu dalam usahanya mencapai tujuan bersama.

\section{Penyusunan Perangkat Tes}

Tes sebagai alat yang digunakan dalam penilaian pengajaran, khususnya sebagai alat penilaian hasil belajar untuk ranah kognitif dikelompokkan atas bentuk uraian dan bentuk objektif. Bentuk uraian terdiri atas bentuk uraian bebas dan bentuk uraian terbatas. Untuk bentuk objektif dikenal bentukbentuk jawaban singkat, benar salah, menjodohkan dan pilihan ganda (Nana Sudjana \& Ibrahim, 2001: 261).

Agar tes berfungsi sebagai alat yang paling tepat dan sesuai dengan informasi yang akan dikumpulkan maka tes tersebut harus direncanakan, karena dengan perencanaan tersebut akan didapatkan ketepatan mengenai apa yang ingin diukur. Perencanaan yang dimaksud adalah penyusunan perangkat tes. Pertimbangan utama dalam perencanaan tersebut ialah menentukan apa yang akan diukur dan menguraikannya, sehingga pertanyaan yang disusun benar-benar mengukur perilaku yang diinginkan (Gronlund, 1982, 18)

Dengan memperhatikan tujuan dan langkah-langkah penulisan alat penilaian, maka diharapkan alat tersebut menjadi alat penilaian yang memenuhi kriteria, dimana efektivitas pengukuran akan tergantung pada validitas, reliabilitas dan kepraktisan penggunaan alat tersebut (Jahja Umar dkk, 1997/1998, 12). Brown mengemukakan pendapatnya bahwa karakteristik alat ukur yang baik apabila 
alat tersebut memenuhi syarat: relevance, adequate sampling, standard condition, appropriate difficulty, consistency score, dan practical matter (Brown, 1981, 15 - 20).

Sebelum soal dirakit menjadi suatu perangkat alat penilaian, sebaiknya setiap butir soal diteliti dan dikaji dengan cara melakukan telaah soal yang didasarkan atas kaidah-kaidah yang dipakai pada penulisan soal. Kaidah penelahaan penulisan soal mencakup penelahaahan materi, konstruksi dan bahasa (Silverius, 1991, 80). Dengan perkataan lain uraian tersebut menunjukkan bahwa perangkat soal yang dibuat akan memiliki kualitas yang baik apabila memiliki tujuan penulisan soal, menempuh langkah-langkah dalam merencanakan perangkat soal, memiliki karakteristik yang baik dan diteliti serta dikaji melalui penelaahan soal.

\section{Kerja kelompok dalam menyusun perangkat alat penilaian.}

Untuk memiliki kemampuan menyusun perangkat alat penilaian, mahasiswa dapat memperolehnya dengan mengikuti kegiatan belajar mengajar mata kuliah Evaluasi Pengajaran di SD. Perlu digaris bawahi bahwa kegiatan belajar mengajar, tidak hanya melalui presentasi atau system kuliah didepan kelas. Bahkan sementara diketakan bahwa metode dengan kuliah (presentasi) tidaklah dianggap sebagai satusatunya proses belajar yang efisien bila ditinjau dari segi pengembangan sikap dan pikiran intelektual yang kritis dan kreatif (Sardiman A.M., 2001, 143).

Metode yang dapat digunakan selain metode dengan kuliah untuk mata kuliah Evaluasi Pengajaran khususnya materi pengembangan alat penilaian adalah kerja kelompok. Bentuk kerja kelompok yang diambil adalah kerja kelonpok berjangka panjang, mengingat materi yang akan dibahas cukup luas dan banyak. Materi penyusunan alat penilaian yang tercakup di dalamnya adalah : (1) menetapkan tujuan penilaian, (2) analisis kurikulum, (3) analisis buku pelajaran dan sumber materi lainnya, (4) menyusun kisi-kisi, (5) menulis TIK/indikator, (6) menulis soal, (7) reproduksi alat penilaian terbatas, (8) uji coba, (9) analisis soal, (10) revisi soal, (11) menentukan soal yang baik, (12) merakit soal menjadi suatu perangkat alat penilaian (Silverius, 1991, 13-15).

Langkah-langkah kerja kelompok dalam pengerjaan penyusunan perangkat alat penilaian adalah :

a. Menjelaskan tugas yang harus dikerjakan oleh mahasiswa,

b. Menjelaskan tujuan kerja kelompok,

c. Membagi mahasiswa ke dalam beberapa kelompok berdasarkan kepada keragaman kemampuan mahasiswa,

d. Setiap kelompok menunjuk seorang pencatat yang akan membuat laporan tentang kemajuan dan hasil kerja kelompok.

Adapun tugas pengajar dalam kerja kelompok ini adalah sebagai pengamat (observer), manajer, penasehat (advisor) dan penilai.

\section{PROSEDUR PENELITIAN}

Penelitian mempergunakan metoda penelitian tindakan kelas. Teknik yang digunakan adalah teknik kuesioner, dokumentasi, dan wawancara. Data diolah dengan menggunakan teknik analisis data kualitatif melalui pengkodean, klasifikasi, analisis, dan interpretasi data.

Penelitian tindakan kelas ini dilaksanakan di semester V PGSD UPI Kampus Cibiru. Subjek penelitian adalag Pengajar mata kuliah Evalusi Pengajaran di SD dan mahasiswa PGSD, yang menjadi sasaran penelitian adalah proses pembelajaran Evaluasi Pengajaran di semester $\mathrm{V}$ dengan menggunakan kerja kelompok untuk meningkatkan kemampuan menyusun alat penilaian berbasis kelas

\section{HASIL PENELITIAN}


Berdasarkan hasil analisis keseluruhan dari tindakan-tindakan pembelajaran yang telah dilaksanakan maka dapat dipaparkan hasil penelitian sebagai berikut:

Pada awal pembelajaran mahasiswa terlihat kurang bersemangat, hal tersebut ditunjukkan mahasiswa dengan sikap membuat kelompok yang tempatnya lebih jauh dari jangkauan pengajar. Selain itu, mahasiswa juga masih berpikir bahwa harus berkelompok dengan mahasiswa yang dinilai sudah menguasai materi agar dapat mewakili kelompoknya dalam melakukan presentasi hasil kegiatan kelompok. Dalam hal ini, pengajar pengajar berinisiatif untuk mengelompokkan mahasiswa dengan mempertimbangkan tingkat kemampuan mahasiswa berdasarkan data yang diperoleh pada kegiatan survey awal. Dengan demikian, dalam kelompok tersebut akan terpupuk kemauan dan kemampuan kerjasama antar anggota kelompok, meningkatnya keterilbatan mahasiswa, emosional dan intelektual para mahasiswa dalam proses belajar-mengajar secara berimbang (Moedjiono \& M. Dimyati, 19911992:61).

Pada kegiatan kelompok tindakan-tindakan serta interaksi antara mahasiswa dengan mahasiswa maupun mahasiswa dengan pengajar kurang aktif. Hal ini ditunjukan oleh sikap dua kelompok yang terlihat pasif dan dalam pengerjaan tugas hanya dilakukan oleh dua dari lima orang anggotanya, sedangkan yang lainnya hanya memperhatikan rekannya yang sedang mengerjakan tugas kelompok. Peristiwa ttersebut terjadi dikarenakan mahasiswa terbiasa menerima pembelajaran sebagai proses alih informasi dari pengajar, dari pada proses pencarian dan penggunaan informasi yang dimiliki mahasiswa untuk memecahkan masalah (A. Tabrani Rusyan, dkk, 2000:7).

Dengan demikian, peran pengajar sangat penting dalam memberikan motivasi bagi mahasiswa untuk belajar aktif dan kreatif, dikarenakan proses pembelajaran akan berhasil apabila pengajar dapat mengkondisikan kegiatan belajar secara aktif. Belajar dengan cara bekerja sama, memberi kesempatam pada para mahasiswa untuk bekerja dalam kelompok-kelompok kecil untuk menyelesaikan atau memecahkan suatu masalah secara bersama-sama. Para mahasiswa juga diberi kesempatan untuk mendiskusikan masalah, menentukan strategi pemecahannya, dan menghubungkan masalah tersebut dengan masalah-masalah lain yang telah dapat diselesaikan sebelumnya. Belajar dengan cara bekerja sama mahasiswa dilatih untuk mendengarkan pendapat orang lain, dapat saling membantu dalam mengintegrasikan pengetahuan-pengetahuan baru dengan pengetahuan yang telah dimilikinya. Sejalan dengan itu, Winataputra (2001:2.11) berpendapat bahwa salah satu cara untuk membangkitkan motivasi ekstrinsik mahasiswa dalam belajar, yaitu dengan menciptakan pembelajaran yang menyenangkan.

Dalam kegiatan analisis kurikulum, setelah ada seorang mahasiswa yang berhasil mencoba mengemukakan pendapatnya, mahasiswa lain termotivasi untuk mendapatkan giliran melakukan analisis. Kenyataan tersebut sesuai dengan pendapat Djiwandono, Sri Esti (2002:79) yang mengemukakan bahwa interaksi yang sukses dengan teman sebaya memerlukan komunikasi dan keterampilan khusus, seperti memprakarsai interaksi, memelihara hubungan, dan menyelesaikan konfilk. Dalam peristiwa perebutan tugas kelompok, pengajar mengambil posisi sebagai penengah dan meminta ketua kelompoknya agar membagi tugas yang harus dikerjakan oleh setiap anggota kelompoknya masing-masing. Tindakan pengajar tersebut sudah memenuhi kompetensi yang disyaratkan Uzer Usman (1995:19) yaitu kemampuan menciptakan iklim belajar mengajar yang tepat melalui pengelolaan kelas yang baik, yang memungkinkan mahasiswa merasa aman untuk belajar, seperti belajar sambil bermain dan bekerja. Pernyataan tersebut diperkuat oleh Winataputra (2001:3.4) yang mengemukakan bahwa proses pembelajaran akan berhasil apabila pengajar dapat mengkondisikan kegiatan belajar secara efektif.

Pada kegiatan pembelajaran selanjutnya mahasiswa terlihat antusias dan mulai terbuka untuk melakukan tanya jawab mengenai pembuatan kisi-kisi dan tujuan pembelajaran, baik dengan pengajar maupun antar mahasiswa. Kegiatan tersebut menunjukkan adanya hubungan timbal balik, tidak bersifat sepihak, dan tidak memandang pengajar sebagai satu-satunya subyek (Suprayekti, 2003:6). Dengan 
demikian dalam pembelajaran tersebut sudah terdapat interaksi (hubungan sosial para mahasiswa dengan pengajar) yang dimana didalamnya terdapat satu pertalian antar individu sehingga individu yang bersangkutan saling mempengaruhi satu sama lainnya (JP. Chaplin, 1999:254). Selain itu Winataputra (2001:8.56) berpendapat bahwa dalam kegiatan berkelompok mahasiswa mendapat kesempatan meningkatkan keterlibatannya dalam kegiatan pembelajaran.Selain itu, pemilihan teori belajar juga dapat memberikan pedoman dalam pembelajaran sehingga bahan ajar dan pelajarannya sesuai dengan tingkat perkembangan mahasiswa, karena hal tersebut dapat membantu serta melatih berpikir mahasiswa yang sistematis, logis, kritis dan konsisten (Depdiknas, 2003:2). Sejalan dengan itu, Winataputra (2001:2.11) berpendapat bahwa salah satu cara untuk membangkitkan motivasi ekstrinsik peserta didik dalam belajar, yaitu dengan menciptakan pembelajaran yang menyenangkan.

Selain itu hasil penelitian menunjukkan adanya peningkatan kemampuan mahasiswa dalam menyusun alat penilaian bentuk pilihan ganda, isian singkat dan uraian. Dengan demikian dapat disimpulkan bahwa terjadinya peningkatan hasil pre-tes dan postes serta keterlibatan mahasiswa dalam menyelesaikan tugas menunjukkan adanya peningkatan kemampuan peserta didik.

Temuan lain yang peneliti peroleh adalah mahasiswa merasa senang dengan cara pengajar menyajikan pelajaran, dan berharap materi lain dapat disampaikan pengajar dengan cara yang sama. Dengan demikian dapat dikemukakan bahwa pengajarlah yang seharusnya menjadi model membangkitkan motivasi belajar mahasiswa dengan mengungkapakan secara bebas rasa ingin tahunya, minatnya, dan tantangan pribadi untuk memecahkan suatu masalah atau melakukan suatu tugas. Pernyataan tersebut diperkuat oleh Winataputra, (2001:8.19) yang mengemukakan bahwa peran pengajar dalam pembelajaran mempunyai hubungan erat dengan cara mengaktifkan mahasiswa dalam belajar, terutama dalam proses pengembangan keterampilan berpikir, keterampilan sosial dan keterampilan praktis.

Dari hasil penelitian juga diperoleh data bahwa pengajar lebih terbuka, menerima dan menghargai mahasiswa, empati serta bersikap demokratis terhadap jawaban dan pertanyaan yang dilontarkan oleh mahasiswa. Kondisi tersebut menunjukkan bahwa karakteristik pengajar yang efektif dalam pengelolaan kelas adalah mendorong dan memelihara minat mahasiswa terhadap tujuan pengajaran serta mempertahankan aktivitas mahasiswa pada proses belajar mengajar dengan menggunakan keterampilan mengajar. Dimana salah satu keterampilan mengajar yang harus dikuasai oleh pengajar adalah keterampilan menumbuhkan kemauan dan kemampuan bertanya (Winataputra, 2001:7.5-7.29). Pemberian kesempatan untuk belajar menemukan dan memecahkan masalah dalam kelompoknya yang didukung oleh kemauan dan kemampuan bertanya mahasiswa, menciptakan pembelajaran yang interaktif.

Dari hasil tersebut secara prosedural kegiatan pembelajaran evaluasi pengajaran dengan kerja kelompok dapat dikatakan berhasil hal ini terbukti dengan tingkat aktifitas belajar mahasiswa semakin meningkat, terjalin kerjasama yang baik dalam kelompok dan mahasiswa lebih dapat memaknai kehadiran teman sekelompoknya. Sedangkan secara konseptual keberhasilan pembelajaran evaluasi pengajaran dibuktikan dengan perolehan nilai yang menunjukan peningkatan pada setiap tindakannya. Dengan demikian dapat disimpulkan bahwa kemampuan mahasiswa PGSD semester 5 dalam menyusun alat penilaian hasil belajar untuk siswa SD dalam pembelajaran evaluasi pengajaran dapat ditingkatkan melalui kegiatan kelompok.

\section{DAFTAR PUSTAKA}

A. Tabrani Rusyan, dkk (2000). Upaya Meningkatkan Budaya Kinerja Pengajar Sekolah Dasar. Jakarta: Nusantara Lestari Ceria Pratama 
Brown, Frederick G., (1981). Measuring Classroom Achievment. Lona: Holt Rinehart and Winston. Depdiknas, (2003). Kurikulum Berbasis Kompetensi : Kebijakan Umum Pendidikan Dasar dan Menengah. Jakarta: Puskur Balitbang Diknnas.

Djiwandono, Sri Esti., (2002). Psikologi Pendidikan. Jakarta: PT. Gramedia Widiasarana Indonesia. Gronlund, Norman E., (1982). Constructing Achievment Test. New Jersey: Prentice Hall Inc.

JP. Chaplin, (1999). Kamus Lengkap Psikologi (terjemahan Kartini Kartono). Jakarta: PT. Raja Grafindo Persada.

Moedjiono dan M.Dimyati, (1991/1992). Strategi Belajar Mengajar. Jakarta: Depdibud Proyek Pembinaan Tenaga Kependidikan.

Nana Sudjana dan Ibrahim, (2001). Penelitian dan Penilaian Pendidikan. Bandung: Sinar Baru Algesindo. Roestiyah N.K., (1989). Strategi Belajar Mengajar. Jakarta: Penerbit Bina Aksara

Sardiman A.M., (2001). Interaksi dan Motivasi Belajar Mengajar. Jakarta: PT. Raja Grafindo Persada Silverius, Suke., (1991). Evaluasi Hasil Belajar dan Umpan Balik. Jakarta: PT Grasindo.

Suprayekti, (2003). Interaksi Belajar Mengajar. Jakarta: Depdiknas, Dirjen Dikdasmen. Usman, Uzer., (1995:19). Menjadi Pengajar Profesional. Bandung: PT. Remaja Rosda Karya.

Wiersma, William dan Stephen G. Jurs., (1991). Educational Measurement and Testing. Massachussets: Allyn and Bacon.

Winataputra (2001). Strategi Belajar Mengajar. Jakarta: Universitas Terbuka.

\section{BIODATA PENULIS}

Realin Setiamiharja dalah Dosen Program Studi S1 PGSD UPI Kampus Cibiru 